\title{
Differences in propionate-induced inhibition of cholesterol and triacylglycerol synthesis between human and rat hepatocytes in primary culture
}

\author{
BY YUGUANG LIN ${ }^{1}$, ROEL J. VONK 1 , MAARTEN J. H. SLOOFF ${ }^{2}$, \\ FOLKERT KUIPERS ${ }^{1 *}$ AND MARTIN J. SMIT \\ ${ }^{1}$ Groningen Institute for Drug Studies (GIDS), Departments of Pediatrics and ${ }^{2}$ Surgery, University \\ Hospital and State University of Groningen. The Netherlands
}

(Received 4 July 1994 - Revised 6 December 1994 - Accepted 6 January 1995)

\begin{abstract}
Propionate is a short-chain fatty acid formed in the colon and supposedly involved in the cholesterollowering effect of soluble fibre. To explore the underlying mechanism(s) of this fibre action, we have used human hepatocytes in primary culture to study the effects of propionate on hepatic lipid synthesis. Initial experiments with mevalonate and mevinolin, a competitive inhibitor of hydroxymethylglutaryl (HMG)CoA reductase ( $E C 1.1 .1 .88)$ were performed to evaluate basic regulatory mechanisms in these cells; results were compared with those obtained with rat hepatocytes. Incubation for $24 \mathrm{~h}$ with mevalonate caused a similar, concentration-dependent inhibition of $\left[{ }^{14} \mathrm{C} \mid\right.$ acetate incorporation into cholesterol in human and rat hepatocytes. Likewise, mevinolin $(100 \mu \mathrm{mol} / \mathrm{l})$ inhibited the formation of cholesterol from radiolabelled acetate by about $80 \%$ in cells from both species. Propionate inhibited cholesterol as well as triacylglycerol synthesis from $\left.I^{14} \mathrm{C}\right]$ acetate with a similar concentration-dependency in rat bepatocytes. Fifty percent inhibition was obtained at a propionate concentration of only $0 \cdot 1 \mathrm{mmol} / \mathrm{l}$. This propionate-induced inhibition was not affected by a 100 -fold excess of unlabelled acetate. Human hepatocytes were much less susceptible in this respect: propionate concentrations of $10-20 \mathrm{mmol} / \mathrm{I}$ were required to obtain similar inhibitory effects in these cells, i.e. values greatly exceeding reported portal propionate concentrations in humans. The results suggest the existence of differences in the regulation of hepatic cholesterol (and triacylglycerol) synthesis between human and rat liver cells. These results do not support the hypothesis that the fibre-induced decrease in plasma cholesterol concentration in man is mediated by a direct effect of propionate on hepatic cholesterol synthesis.
\end{abstract}

Liver: Cholesterol: Triacylglycerol: Short-chain fatty acids

The liver is the major site of regulation of body cholesterol homeostasis (Dietschy, 1986). Regulatory steps in hepatic cholesterol metabolism have been studied extensively using cultured rat hepatocytes and human hepatoma cells. Potential drawbacks of using animal or tumour cells concern the well-established species-specific and tumour-specific characteristics respectively, of hepatic cholesterol metabolism. Cultured human hepatocytes therefore provide a very useful tool to obtain information on human-specific characteristics of hepatic cholesterol metabolism. A few studies on cholesterol metabolism have been performed so far using human hepatocytes. From these studies it has become clear that in vitro these cells express low-density-lipoprotein (LDL)-receptor activity (Edge et al. 1986; Hoeg et al. 1986; Kamps et al. 1991) and high-affinity binding sites for $\beta$-migrating verylow-density lipoprotein ( $\beta$-VLDL) (De Water et al. 1992) and apolipoprotein E-free highdensity lipoprotein (HDL) (Schouten et al. 1990). In addition, they have been shown to

* For reprints. 
synthesize and secrete bile acids (Princen et al. 1986), albumin (Forte et al. 1989), and lipoproteins (Forte et al. 1989). Furthermore, apolipoprotein B secretion by human hepatocytes is inhibited by insulin (Salhanick et al. 1991), a phenomenon also observed with rat hepatocytes. Regulation of LDL-receptor activity in human hepatocytes in response to incubation with LDL and heavy HDL has been demonstrated by Havekes $e t$ al. (1986).

The high incidence of coronary heart disease in Western countries is, at least in part, related to nutritional factors that interact with cholesterol metabolism. Dietary fibre is one of the dietary components known to affect cholesterol metabolism in humans and experimental animals (Kritchevsky, 1986). In particular, water-soluble fibre has been suggested for use as a serum-cholesterol-lowering, anti-atherogenic agent (Kirby et al. 1981; Anderson et al. 1984). One of the proposed mechanisms for the hypocholesterolaemic effect of soluble fibre is through the action of propionate, a short-chain fatty acid that arises from fibre fermentation in the colon (Chen \& Anderson, 1984). Propionate has been reported to inhibit lipid synthesis in vitro in rat hepatocytes (Nishina \& Freedland, 1990; Wright et al. 1990). For the present studies we have used human hepatocytes in primary culture to study the human-specific effects of propionate on lipid synthesis and have compared the results with those obtained with rat hepatocytes.

\section{MATERIALS AND METHODS \\ Materials}

$\left[2-{ }^{14} \mathrm{C}\right]$ Acetic acid $(2097 \mathrm{kBq} / \mathrm{mmol})$ and $\mathrm{L}-\left[4,5{ }^{3} \mathrm{H}\right]$ leucine $(2257 \mathrm{GBq} / \mathrm{mmol})$ were obtained from the Radiochemical Centre Ltd., Amersham, Bucks. Mevinolin (MK-803) was a kind gift from the Merck, Sharp and Dohme Research Laboratory, Rahway, NJ, USA. Mevalonic acid lactone was purchased from Sigma Chemical Co., St. Louis, MO, USA. Insulin (Actrapid, $100 \mathrm{IU} / \mathrm{ml}$ ) was from Novo Nordisk Industry A/S (Copenhagen, Denmark). Thin-layer chromatography (TLC) precoated silica gel 60 plates and all salts and solvents were obtained from E. Merck (Darmstadt, Germany).

\section{Rat hepatocytes}

For isolation of rat hepatocytes, male Wistar rats weighing $180-220 \mathrm{~g}$ were used. Rats were maintained in a light- and temperature-controlled room. Lights were on from 06.00 to 18.00 hours. Water and pellet food (RMH-B, Hope Farms, The Netherlands) were available $a d$ lib. Hepatocytes were isolated according to the method of Berry \& Friend (1969) and cultured exactly as described below for human hepatocytes.

\section{Human hepatocytes}

Human liver tissue was obtained from livers harvested from multiorgan donors (two female, five male, aged 5-42 years). Consent from legal authorities and family was obtained for the explantation of organs for transplantation purposes. The donor livers were split to perform reduced-size liver transplants in children. The liver tissue remaining after the splitting procedure was used for the isolation of hepatocytes. Some livers discarded for transplantation after harvesting were used as well. Livers were perfused with UW (University of Wisconsin) solution (Kalayoglu et al. 1988) and stored in this buffer at $4^{\circ}$ until the start of the isolation procedure. Hepatocytes were isolated from $13-130 \mathrm{~g}$ pieces of liver tissue as described by Sandker et al. (1994), after 6 to $41 \mathrm{~h}$ preservation in UW solution. When the viability of the cells, as judged by Trypan Blue exclusion, was lower than $70 \%$ the non-viable cells were separated from viable ones by suspending the cells in 
$36 \%$ Percoll, followed by centrifugation for $10 \mathrm{~min}$ at $100 \mathrm{~g}$. The Percoll solution with nonviable cells on top was discarded and the pellet consisting of viable hepatocytes was washed and resuspended in Krebs-Henseleit buffer and the number of cells was counted.

Cells were cultured as described previously (Princen et al. 1986). In short, the cells were washed twice in the culture medium described below and seeded on 6-well cluster plates (35 mm diameter; Costar, Cambridge, MA, USA) at a density of $1.5 \times 10^{6}$ cells $/$ well and were maintained in Williams $\mathrm{E}$ medium supplemented with $100 \mathrm{~g}$ heat-inactivated fetal bovine serum/l, $2 \mathrm{~mm}$-L-glutamine, $4 \mathrm{mU}$ insulin $/ \mathrm{ml}, 50 \mathrm{nM}$ dexamethasone, $100 \mathrm{IU}$ penicillin $/ \mathrm{ml}$, and $100 \mu \mathrm{g}$ streptomycin $/ \mathrm{ml}$ at $37^{\circ}$ in a $\mathrm{CO}_{2}$-air $(5: 95 \mathrm{v} / \mathrm{v})$ atmosphere. After attachment of the cells $(4-16 \mathrm{~h}$ ) the medium was renewed with $2 \mathrm{ml}$ culture medium after which medium was renewed every $24 \mathrm{~h}$.

\section{Analyses}

Cholesterol and cholesterol ester were determined, after extraction (Bligh \& Dyer, 1959), according to the method of Gamble et al. (1978). Protein was determined according to the method of Lowry et al. (1959) with bovine serum albumin as a standard. Lactate dehydrogenase (EC 1.1.1.27) in medium and cells was determined as described previously (Smit et al. 1988). Protein synthesis from $\left[{ }^{3} \mathrm{H}\right]$ leucine was measured after $1 \mathrm{~h}$ incubation of cells in serum-free medium containing $185 \mathrm{kBq}\left[{ }^{3} \mathrm{H}\right]$ leucine. The amount of newly synthesized protein in the cells was measured by precipitation of the protein in trichloroacetic acid $(100 \mathrm{~g} / \mathrm{l})$. After centrifugation for $10 \mathrm{~min}$ at $12000 \mathrm{~g}\left(4^{\circ}\right)$ the pellet was washed three times by repeated sonication and centrifugation. The precipitated protein was solubilized overnight at $4^{\circ}$ in $1 \mathrm{ml}$ of a $1.15 \mathrm{M}-\mathrm{NaOH}$ solution containing $11.5 \mathrm{~g} / 1$ sodium dodecyl sulphate and the amounts of radioactivity and protein were determined.

\section{Experimental procedures}

After 2-4 d in culture (depending on the type of experiment, see below), cells were washed twice with serum-free medium and the effects of various treatments on cholesterol and in some cases triacylglycerol synthesis were determined by measuring incorporation of $\left[{ }^{14} \mathrm{C}\right]$ acetate into cholesterol and triacylglycerols by incubation for $1 \mathrm{~h}$ in $2 \mathrm{ml}$ serum-free medium containing $185 \mathrm{kBq}\left[{ }^{14} \mathrm{C}\right]$ acetate $(0.1 \mathrm{mmol} / \mathrm{l})$. After $1 \mathrm{~h}$ cells were put on ice, and medium and cells were harvested. Cellular lipids were extracted (Bligh \& Dyer, 1959) and lipids were saponified in tubes containing $20 \mu \mathrm{g}$ and 20000 disintegrations/min (dpm) $\left[{ }^{3} \mathrm{H}\right]$ cholesterol as an internal standard, $45 \mu 1$ glycerol and $3.5 \mathrm{ml}$ ethanolic $\mathrm{KOH}(57 \mathrm{~g} / 1)$ for $1 \mathrm{~h}$ at $90^{\circ}$. The solution was dried under $\mathrm{N}_{2}$ and after a second extraction the lipids were separated by TLC with benzene-ethylacetate $(2: 3, \mathrm{v} / \mathrm{v})$ as a solvent. The cholesterol spot was located by $I_{2}$ vapour, scraped off and the radioactivity was measured in a liquid scintillation counter (LKB Instruments, Uppsala, Sweden) equipped with an external standard to correct for quenching. The amount of labelled triacylglycerol was determined after extraction of cellular lipids and TLC using hexane-diethyl ether-acetic acid $(80: 20: 1$, by vol.) as a solvent.

For experiments on the effect of mevalonate on the incorporation of $\left[{ }^{14} \mathrm{C}\right]$ acetate into cellular cholesterol, mevalonate was added to concentrations of 1-10 $\mathrm{mmol} / 1$. Mevalonate was obtained from mevalonolactone after incubation in $0.1 \mathrm{M}-\mathrm{NaOH}\left(56^{\circ}, 15 \mathrm{~min}\right)$. For these experiments cells that had been cultured for $4 \mathrm{~d}$ in serum-containing medium were used. The medium was changed to serum-free medium containing mevalonate and after

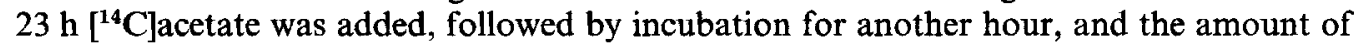
labelled cholesterol was determined as described above. The short-term effect of mevalonate was determined during $1 \mathrm{~h}$ incubation in serum-free medium in the presence of $5 \mathrm{~mm}$ mevalonate. In experiments on the effects of mevinolin, $5 \mu \mathrm{l}$ of a mevinolin solution in 
ethanol was added to $2 \mathrm{ml}$ culture medium to obtain a final concentration of $100 \mu \mathrm{mol} / 1$ and cells were incubated for $1 \mathrm{~h}$ in the presence of $\left[{ }^{14} \mathrm{C}\right]$ acetate.

Experiments with propionate were performed with cells that had been cultured for $2 \mathrm{~d}$ in serum-containing medium. Cells were washed twice with serum-free medium and the incorporation of $\left[{ }^{14} \mathrm{C}\right]$ acetate into cholesterol and triacylglycerols was measured as described above during $1 \mathrm{~h}$ incubations in the absence and presence of propionate at concentrations of $0 \cdot 1-50 \mathrm{mmol} / 1$.

\section{Statistics}

Results are presented as $\mathrm{dpm} / \mathrm{mg}$ protein per $\mathrm{h}$ for individual experiments (mean of triplicate measurements) and as percentage of control values when data from separate isolations are combined. Student's $t$ test was used to evaluate the statistical significance of differences with the control situation, with a $P$ value $<0.05$ considered as significant.

\section{RESULTS}

Cholesterol synthesis from $\left[{ }^{14}\right.$ C]acetate in human hepatocytes

Cholesterol synthesis was estimated in the present study from the incorporation of radiolabelled acetate into the sterol. Incorporation of $\left[{ }^{14} \mathrm{C}\right]$ acetate into cholesterol in the various preparations of human hepatocytes showed large variation and tended to decrease with increasing time in culture. Thus, in 2-d-cultured cells (three preparations, used for propionate experiments) the basal incorporation rates (mean of triplicate measurements) were 90740 (SE 14930), 87230 (SE 6680), and 53600 (SE 9110) dpm/mg protein per $\mathrm{h}$ respectively. Values for 4-d-cultured cells (four preparations, used for mevalonate/ mevinolin experiments) were 14590 (SE 1690), 67670 (SE 7520), 2400 (SE 360), and 1870 (SE 60) $\mathrm{dpm} / \mathrm{mg}$ protein per $\mathrm{h}$ respectively. No clear relationship between incorporation rate on the one hand and donor age, sex or preservation time on the other hand was observed, nor were clear differences observed between cells isolated from discarded livers and those from transplanted ones. On average, synthesis by human hepatocytes was markedly higher than by rat hepatocytes cultured in parallel, i.e. mean 45440 (SE $14690 ; n$ 7) v. mean 4210 (SE $1130 ; n$ 9) $\mathrm{dpm} / \mathrm{mg}$ protein per $\mathrm{h}$ respectively.

\section{Effects of mevalonate and mevinolin}

Incubation of human and rat hepatocytes with different concentrations of mevalonate for $24 \mathrm{~h}$ resulted in similar concentration-dependent down-regulation of cholesterol synthesis from $\left[{ }^{14} \mathrm{C}\right]$ acetate (Fig 1). Incubation of rat hepatocytes for only $1 \mathrm{~h}$ in the presence of $5 \mathrm{~mm}$-mevalonate resulted in down-regulation by $85 \%$ compared with the control value (Fig. 1(b)). Human hepatocytes showed a smaller decrease after a $1 \mathrm{~h}$ incubation, i.e. by $38 \%$ (Fig. 1(a)). The masses of cholesterol and cholesterol ester were slightly higher in rat (16.92 (SE 2.27) and 4.34 (SE 9.57) $\mu \mathrm{g} / \mathrm{mg}$ protein respectively) than in human cells (13.75 (SE 1.85 ) and 2.23 (SE 0.36) $\mu \mathrm{g} / \mathrm{mg}$ respectively). The amount of cholesterol ester was only marginally, i.e. by $20-30 \%$, increased by mevalonate in rat hepatocytes, but more strongly in human cells, i.e. by $60-160 \%$, depending on the mevalonate concentration. To see whether the slow inhibition of cholesterol synthesis was specific for the human cells, we carried out a similar experiment with the human hepatoma cell line HepG2. With these cells we observed a similar concentration-dependent down-regulation after $24 \mathrm{~h}$ incubation with mevalonate as in the primary cultures. Like the human hepatocytes, the HepG2 cells showed only a relatively small inhibition of cholesterol synthesis from radiolabelled acetate, i.e. by $30 \%$, when incubated for $1 \mathrm{~h}$ with $5 \mathrm{~mm}$-mevalonate (Fig. $1(\mathrm{c})$ ).

Mevinolin $(100 \mu \mathrm{mol} / 1)$ caused a similar inhibition of the incorporation of radiolabelled acetate into cholesterol in human and rat hepatocytes, i.e. to 16 (SE 11) \% and 20 (SE 12) \% 


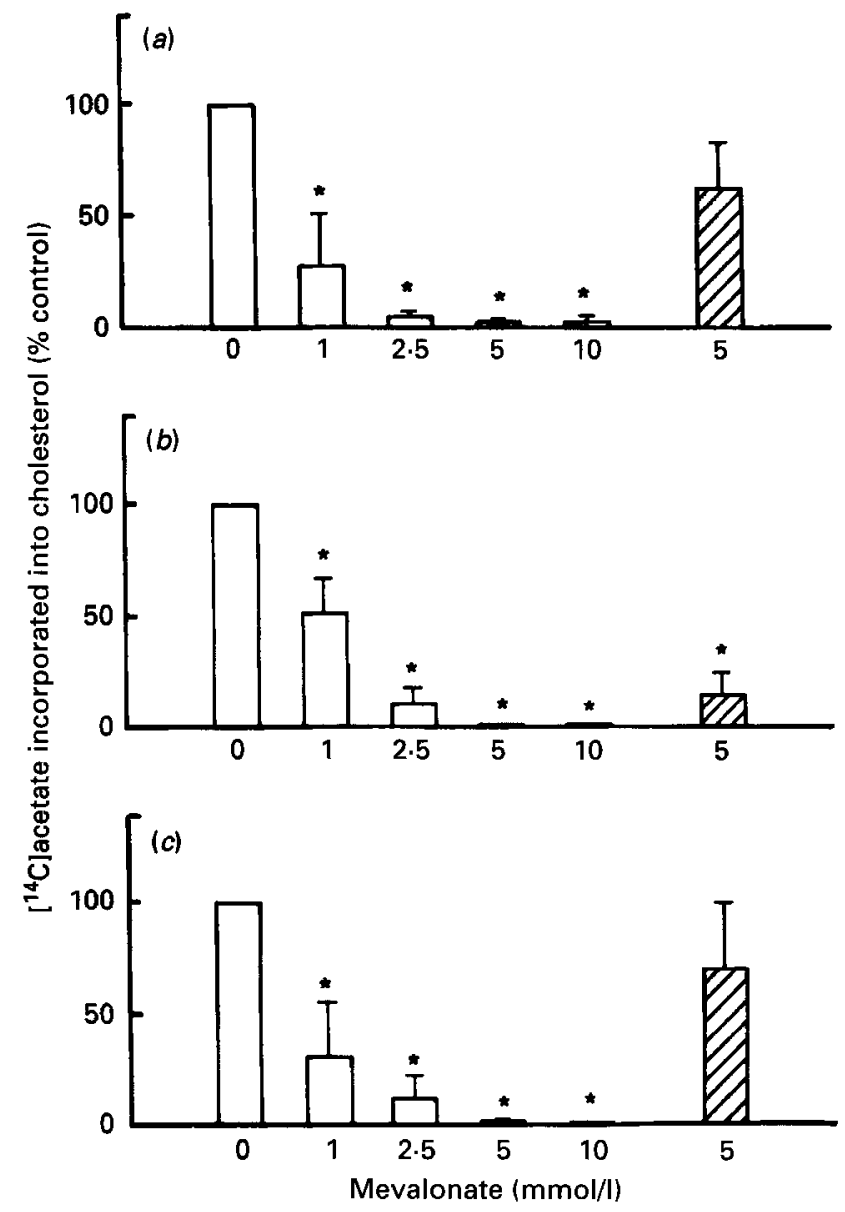

Fig. 1. Effect of mevalonate on the incorporation of $\left[{ }^{14} \mathrm{C}\right]$ acetate into cholesterol in $(a)$ human hepatocytes, $(b)$ rat hepatocytes and $(c)$ HepG2 cells. Cells were incubated for $24 \mathrm{~h}$ in serum-free medium containing the indicated amount of mevalonate. After $23 \mathrm{~h}\left[{ }^{14} \mathrm{C}\right]$ acetate was added to the medium followed by incubation for another $1 \mathrm{~h}$. At $24 \mathrm{~h}$ cells and medium were harvested and analysed as described on p. 199. Hatched bars indicate incubations for $1 \mathrm{~h}$ in serum-free medium with $5 \mathrm{~mm}$-mevalonate. Values are means for triplicate determinations of three different cell preparations, with their standard errors indicated by vertical bars. Total $(100 \%)$ values for cholesterol synthesis were: human hepatocytes 23779 (SE 37838), rat hepatocytes 1947 (SE 496) and HepG2 cells 15062 (SE 10060) dpm/mg protein. * Mean values were significantly different from the control, $P<0.05$.

(three preparations of each species) of the control values respectively. No significant effects on the cellular amounts of free and esterified cholesterol were observed.

\section{Effect of propionate on $\left[{ }^{14} \mathrm{C}\right]$ acetate incorporation into cholesterol and triacylglycerols}

When human hepatocytes were incubated in the presence of different concentrations of propionate, a concentration-dependent inhibition of cholesterol and triacylglycerol synthesis from $\left[{ }^{14} \mathrm{C}\right]$ acetate was observed, with $50 \%$ inhibition occurring at a concentration of about $20 \mathrm{mmol} / 1$ (Fig. 2). The same experiment with rat hepatocytes showed inhibition at much lower concentrations of propionate, i.e. $50 \%$ inhibition at about $0 \cdot 1 \mathrm{mmol} / 1$. In both species inhibition of cholesterol and triacylglycerol fatty acid synthesis took place in a parallel fashion (compare Figs. $2(a)$ and $2(b)$. As a result, the amount of $\left[{ }^{14} \mathrm{C}\right]$ acetate incorporated into cholesterol relative to triacylglycerol was fairly constant over the range 

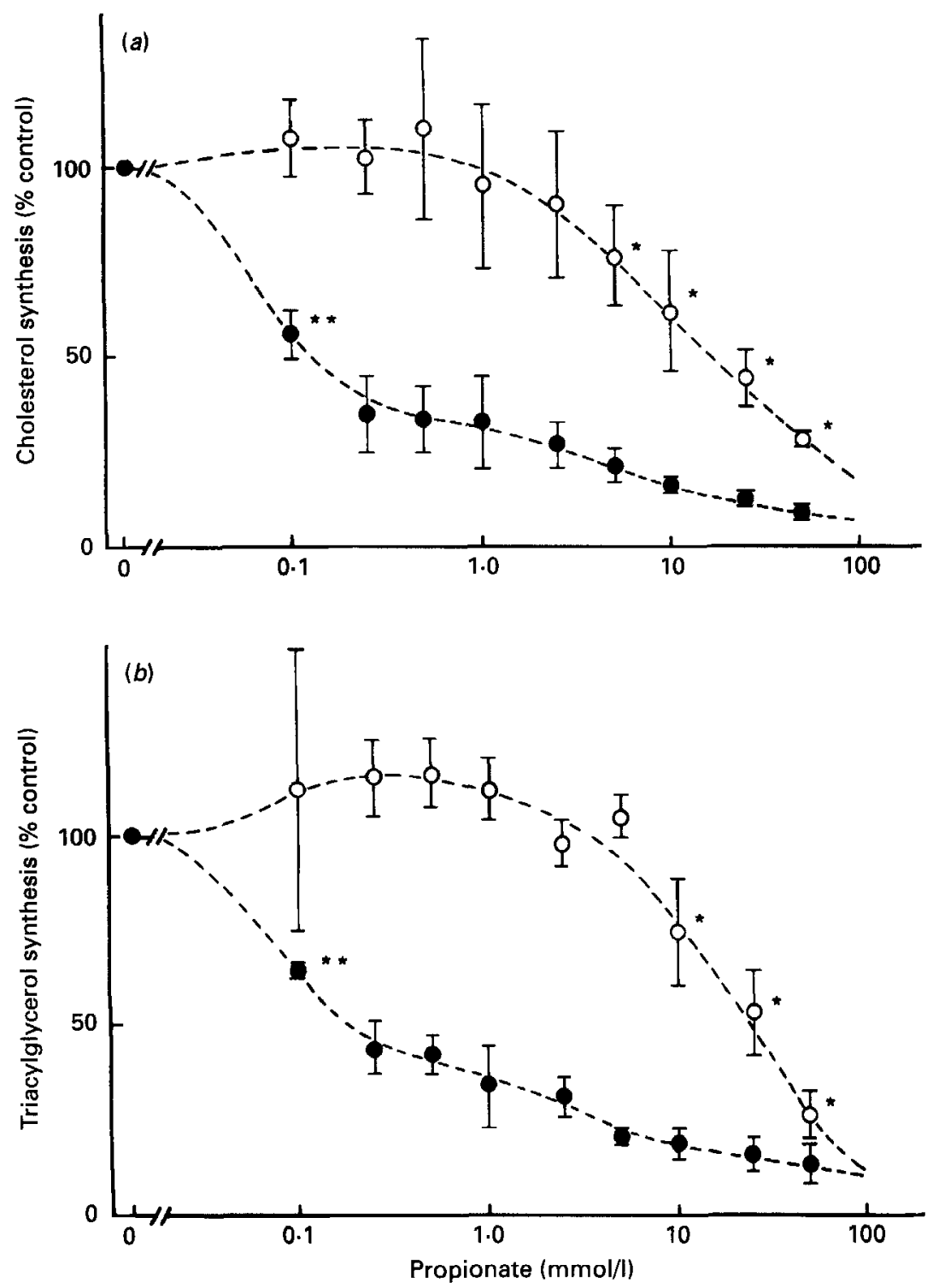

Fig. 2. Effect of propionate on $(a)$ cholesterol and $(b)$ triacylglycerol synthesis from $\left[{ }^{14}\right]$ acetate by human $(O)$ and rat (O) hepatocytes in culture. Synthesis rates were determined during a $1 \mathrm{~h}$ incubation period in the absence and presence of the indicated concentrations of propionate. Values are means of triplicate determinations from three different cell preparations, with their standard errors indicated by vertical bars. The $100 \%$ values for cholesterol synthesis were: human hepatocytes 103600 (SE 53400), rat hepatocytes 9290 (SE 1987) dpm/mg protein, and those for triacylglycerol synthesis were: human hepatocytes 55300 (SE 29900), rat hepatocytes 17960 (SE 4960) dpm/mg protein. * Mean values for human hepatocytes were significantly different from controls, $P<0.05$. ** Mean values for rat hepatocytes were significantly different from controls from a propionate concentration of $0.1 \mathrm{mmol} / 1$ upward (asterisks not included in Fig. for reasons of clarity). For details of procedures, see pp. 198-200.

of propionate concentrations used. In rat hepatocytes the ratio between ${ }^{14} \mathrm{C}$ incorporated into triacylglycerol and cholesterol was about $2 \cdot 5: 1$. With two preparations of human hepatocytes values of $<0.5: 1$ were observed. In another preparation this ratio was about $2: 1$. 


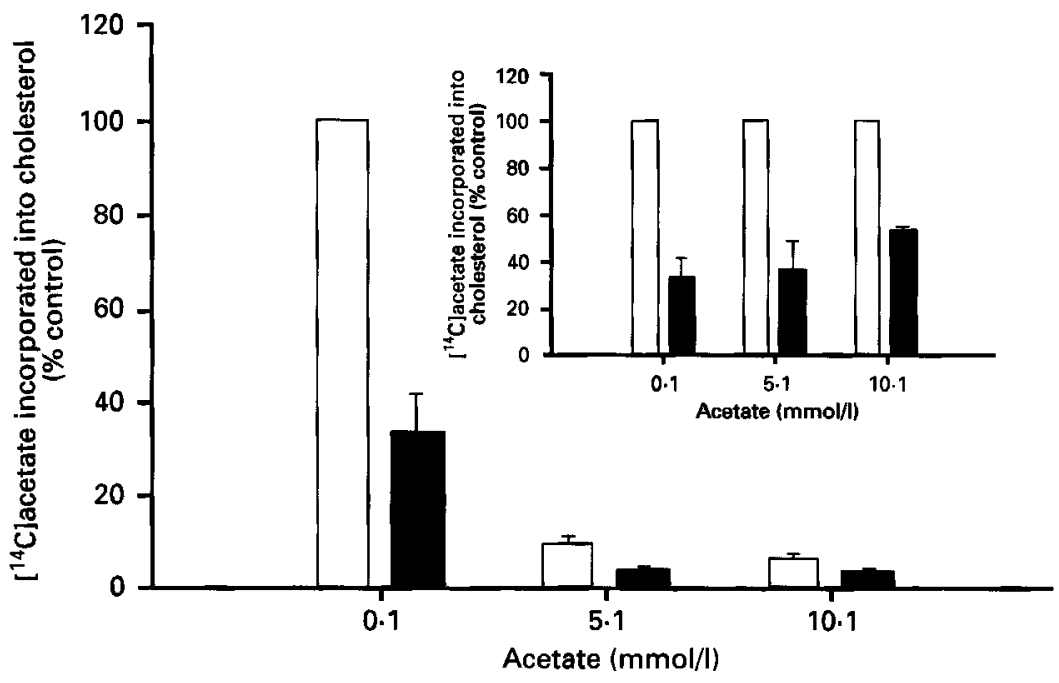

Fig. 3. Effect of different concentrations of acetate on the inhibition by propionate of $\left[{ }^{14} \mathrm{C}\right]$ acetate incorporation into cholesterol in rat hepatocytes. Rat hepatocytes were incubated in serum-free medium for $l \mathrm{~h}$ in the presence of $185 \mathrm{kBq}\left[{ }^{14} \mathrm{C}\right]$ acetate at concentrations of $0 \cdot 1,5 \cdot 1$ and $10 \cdot 1 \mathrm{mmol} / \mathrm{l}$ in the absence $(\square)$ or presence $(\square)$ of $0.5 \mathrm{~mm}$-propionate. Results are shown as a percentage of the control incubations with $0.1 \mathrm{~mm}$-acetate and represent means of determinations from three cell preparations with their standard errors indicated by vertical bars. The insert shows the same results, but in this case the value of the incubation without propionate ( $\square$ ) at each concentration of $0 \cdot 1,5 \cdot 1$ and $10 \cdot 1 \mathrm{~mm}$-acetate is taken as $100 \%$. For details of procedures, see pp. 198-200.

Table 1. Effect of propionate on protein synthesis by cultured human and rat hepatocytes, and on leakage of lactate dehydrogenase ( $\mathrm{LDH}$; EC 1.1.1.27) into the medium*

(Mean values with their standard errors for triplicate determinations from three different cell preparations)

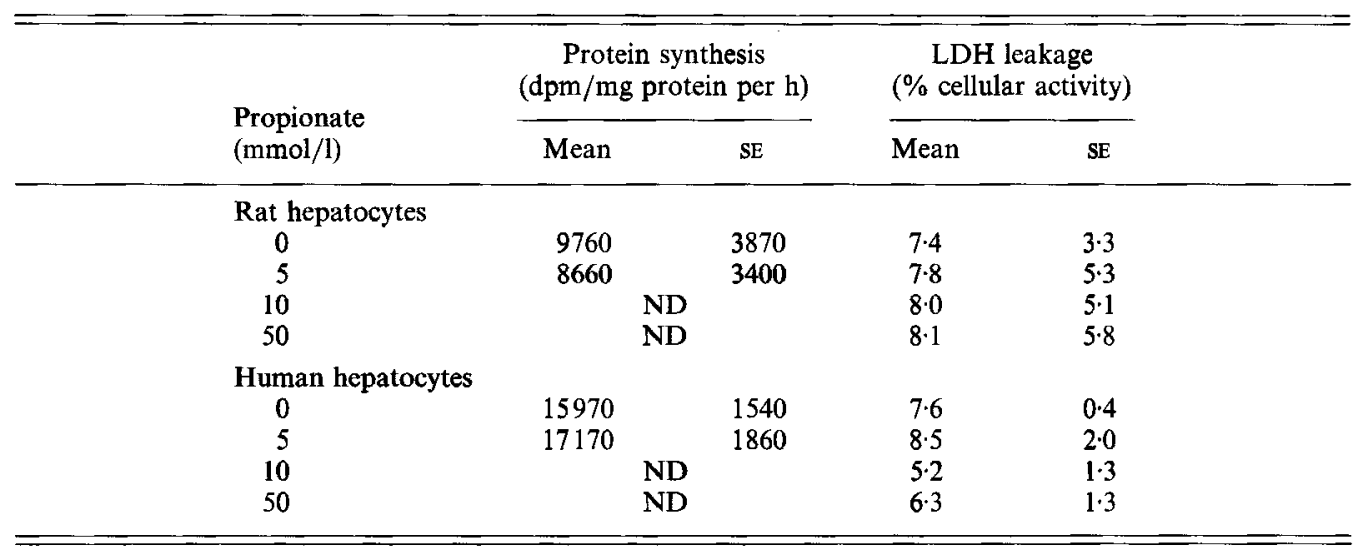

ND, not determined.

* For details of procedures, see pp. 198-200.

To check the possibility that the observed effect on lipid synthesis from $\left[{ }^{14} \mathrm{C}\right]$ acetate was the result of dilution of the substrate pool used for cholesterol synthesis, we carried out an experiment using rat hepatocytes in the presence of a constant concentration of propionate $(0.5 \mathrm{mmol} / \mathrm{l})$ and different concentrations of acetate, i.e. $0.1 \mathrm{~mm}-\left[{ }^{14} \mathrm{C}\right]$ acetate in the presence of 0,5 or $10 \mathrm{mmol} / 1$ unlabelled acetate. The amount of acetate present did not 
affect the propionate-induced inhibition of cholesterol synthesis from radiolabelled acetate, as shown in Fig. 3. A similar result was obtained for triacylglycerol synthesis (results not shown).

Protein synthesis from $\left[{ }^{3} \mathrm{H}\right]$ leucine and leakage of lactate dehydrogenase from the cells was measured in the presence or absence of different concentrations of propionate. As shown in Table 1, there was no effect of propionate on these variables.

\section{DISCUSSION}

The results of the present study demonstrate that human hepatocytes under the culture conditions employed, in general, express similar 'basic features' in their regulation of cholesterol synthesis to those of rat hepatocytes. Thus, synthesis in cells of human and rat origin was strongly inhibited by physiological (mevalonate, propionate) and pharmaceutical (mevinolin) agents and stimulated in the presence of human HDL (150 $\mu \mathrm{g}$ cholesterol/well; results not shown). However, marked quantitative differences between the cells from both species were observed that in the case of propionate-induced effects may be indicative of physiologically relevant species differences in the regulation of hepatic lipid synthesis.

In these studies we applied radiolabelled acetate to estimate cholesterol (and triacylglycerol) synthesis; because of the well-established compartmentalization of cellular acetate this method does not allow the calculation of absolute synthesis rates (Turley \& Dietschy, 1982), and values were expressed as $\mathrm{dpm} / \mathrm{mg}$ protein or as relative changes compared with control conditions. Although $\left[{ }^{14} \mathrm{C}\right]$ acetate is not suitable for determination of absolute synthesis rates, as discussed in detail by Turley \& Dietschy (1982), it has been demonstrated that the relative changes in cholesterol biosynthesis measured by this method in cultured cells under different experimental conditions are in close agreement with values obtained with tritiated water (Davis et al. 1982).

On average, $\left[{ }^{14} \mathrm{C}\right]$ acetate incorporation into cholesterol was higher in human hepatocytes than in rat hepatocytes. Under normal feeding conditions the rat appears to have a relatively high rate of hepatic and total body cholesterol synthesis when compared with other animal species (Turley \& Dietschy, 1982). Likewise, the absolute synthesis of cholesterol measured by ${ }^{3} \mathrm{H}_{2} \mathrm{O}$ in liver slices was found to be five times higher in rat than in human liver (Turley \& Dietschy, 1982). On the other hand, using the newly developed technique of mass isotopomer distribution analysis (MIDA) with infusion of $\left[{ }^{13} \mathrm{C}\right]$ acetate, Hellerstein and co-workers (Neese et al. 1993) very recently calculated values for total body cholesterol synthesis in vivo of 9 to $10 \mathrm{mg} / \mathrm{kg}$ per d and $8.9 \mathrm{mg} / \mathrm{kg}$ per d in healthy female volunteers and male rats respectively. The relative contribution of the liver to total synthesis amounts to $60 \%$ in rats (Turley et al. 1981) but is unknown in humans. Therefore, the relevance of the observed higher acetate incorporation in human cells in vitro when compared with rat cells is difficult to evaluate. It may reflect a difference between the cells of the two species in response to the culture conditions, a possibility supported by differential effects of the presence of fetal bovine serum and human lipoproteins in the media on cholesterol synthesis and cellular cholesterol ester content in human and rat cells (Y. Lin, R. Havinga, M. J. Smit and F. Kuipers, unpublished results). It may also be a metabolic effect of the preservation of human liver tissue in UW solution; this possibility is currently under investigation in our laboratory. On the other hand, it may be a reflection of differences in the size of cytosolic acetate pools between human and rat cells, a factor that may also contribute to the marked variability in acetate incorporation between the different human hepatocyte preparations. Nevertheless, mevinolin, a competitive inhibitor of hydroxymethylglutaryl (HMG)-CoA reductase (EC 1.1.1.88), and mevalonate inhibited 
the incorporation of $\left[{ }^{14} \mathrm{C}\right]$ acetate into cholesterol to the same extent in cells from both species, independent of the basal incorporation rates. Mevalonate, formed from hydroxymethylglutaryl (HMG)-CoA in a reaction catalysed by $\mathrm{HMG}-\mathrm{CoA}$ reductase ( $E C$ 1.1.1.88), has been shown to influence cholesterol metabolism via both sterol (possibly oxysterols) and non-sterol products (Goldstein \& Brown, 1980; Nakanishi et al. 1988). Drevon et al. (1980) showed that, on incubation of rat hepatocytes with mevalonate ( $1 \mathrm{mmol} / \mathrm{l}$ ), HMG-CoA reductase activity decreased to a level of about $20 \%$ of the control value within $1 \mathrm{~h}$. We observed a similar, dose-dependent decrease in cholesterol synthesis from $\left[{ }^{14} \mathrm{C}\right]$ acetate in rat and human hepatocytes, as well as in $\mathrm{HepG} 2$ cells, after $24 \mathrm{~h}$ incubation with different concentrations of mevalonate. After only $1 \mathrm{~h}$ incubation with 5 mM-mevalonate a strong inhibition was observed in rat hepatocytes, in agreement with the results of Drevon et al. (1980). Both in human hepatocytes and in HepG2 cells the inhibition was less pronounced after $1 \mathrm{~h}$, indicating that human cells do not react as rapidly as rat cells to changes in cholesterol availability. Accordingly, an increased amount of cholesterol ester was found in human hepatocytes and in HepG 2 cells, but not in rat cells, after incubation with mevalonate.

The interference of propionate with hepatocytic cholesterol synthesis was studied to see whether propionate may act as a mediator of the cholesterol-lowering effect of soluble fibre in humans. Propionate, as well as the other short-chain fatty acids acetate and butyrate, is formed by fermentation of soluble and insoluble fibres by colonic microflora. After absorption it is effectively cleared by the liver (Dankert et al. 1981).

Propionate has been shown to lower serum cholesterol concentrations when fed to rats (Illman et al. 1988) and to inhibit the synthesis of cholesterol (and of fatty acids) from $\left[{ }^{14} \mathrm{C}\right]$ acetate in freshly isolated rat hepatocytes (Nishina \& Freedland, 1990; Wright et al. 1990 ) in the concentration range observed in the portal blood of rats fed on high-fibre diets, i.e. up to $0.8 \mathrm{mmol} / 1$ (Illman et al. 1988). Very recently, Todesco et al. (1991) reported that supplementing the diet of healthy volunteers with sodium propionate $(9 \cdot 9 \mathrm{~g} / \mathrm{d})$ for 1 week tended to reduce LDL-cholesterol concentrations, with an average reduction of $0.37 \mathrm{mmol} / 1$. However, HDL-cholesterol was also reduced and the triacylglycerol concentration was increased in five out of the six subjects studied.

Using rat hepatocytes in primary culture, we found a parallel, dose-dependent inhibition of cholesterol and triacylglycerol synthesis from $\left[{ }^{14} \mathrm{C}\right]$ acetate, with $50 \%$ inhibition occurring at a propionate concentration as low as $0.1 \mathrm{mmol} / 1$. Propionate did not exert overt toxic effects on liver cells, as concentrations up to $5 \mathrm{mmol} / 1 \mathrm{did}$ not affect protein synthesis and lactate dehydrogenase leakage from the cells. The mechanism of propionateinduced inhibition of lipid synthesis in rat hepatocytes is unclear. Using a 10- and 100-fold excess of radiolabelled acetate, we have excluded the theoretical possibility that propionate competes with acetate for lipid synthesis, in other words that the decreased incorporation of radiolabel into cholesterol is due to dilution of the precursor pool rather than to inhibition of synthesis. It may be that propionate acts on cholesterol and triacylglycerolfatty acid synthesis by affecting the activity of a common key enzyme, e.g. acetyl-CoA synthetase (EC 6.2.1.3), as suggested by the parallel fashion of inhibition of both lipids. Recently, Gordon \& Crabtree (1992) reported a strong inhibition of cytoplasmic acetyl CoA synthesis by $2 \mathrm{~mm}$-propionate in freshly isolated rat hepatocytes. Potential mechanisms also include alteration of the cytosolic citrate concentration and redistribution of CoA (Brass \& Ruff, 1992). Conflicting results on this issue have recently been reported. Wright et al. (1990) and Nishina \& Freedland (1990) found that the synthesis of both cholesterol and fatty acids from $\left[1{ }^{14} \mathrm{C}\right]$ acetate was inhibited by propionate in freshly isolated rat hepatocytes. However, Wright et al. (1990) reported that synthesis of cholesterol, but not that of fatty acids, was inhibited by propionate when ${ }^{3} \mathrm{H}_{2} \mathrm{O}$ was used 
to quantify lipid synthesis, whereas exactly the opposite was found by Nishina \& Freedland (1990). Clearly, more research is needed to clarify this issue.

Propionate concentrations have been determined in human portal blood obtained at autopsy of sudden death victims (within 4 h of death; Cummings et al. 1987) and during gallbladder surgery (Dankert et al. 1981). Values ranging from 0.017-0.194 mmol/l and $0.004-0.108 \mathrm{mmol} / 1$ respectively were found. Obviously, it is not known how these values relate to 'physiological values', for instance the levels reached after a fibre-rich meal. Nevertheless, the measured values are orders of magnitude lower than the propionate concentrations required to inhibit cholesterol (and fatty acid) synthesis in cultured human hepatocytes, i.e. $10-20 \mathrm{mmol} / 1$. The reason(s) for the large difference in susceptibility to propionate-induced inhibition of lipid synthesis between human and rat hepatocytes is not known. The extremely high concentration needed in human cells suggests an aspecific mode of action, like altering the available amount of CoA (Brass \& Ruff, 1992), whereas in rat cells a more specific, potentially 'regulatory' mechanism may operate. These results, therefore, do not support the hypothesis that the cholesterol-lowering effect of soluble fibre in man is mediated by a direct action of propionate on hepatic cholesterol synthesis. In addition, the very distinct species-differences in susceptibility of lipid synthesis to the inhibitory effects of propionate between human and rat cells delineate the suitability of the human hepatocyte system as a model of choice to study the regulation of human hepatic cholesterol metabolism by dietary factors.

This study was supported by grants from the Netherlands Ministry of Health and the Fokkens-Kerkhoff Foundation. YL is supported by the Royal Netherlands Academy of Arts and Sciences. FK is an established investigator of the Netherlands Heart Foundation. These studies were performed in collaboration with the Groningen Human Liver Group.

\section{REFERENCES}

Anderson, J. W., Story, L., Sieling, B., Chen, W., Petro, M. S. \& Story, J. (1984). Hypocholesterolemic effects of oat-bran or bean intake for hypercholesterolemic men. American Journal of Clinical Nutrition 40, 1146-1155.

Berry, M. N. \& Friend, D. S. (1969). High-yield preparation of isolated rat liver parenchymal cells. A biochemical and fine structural study. Journal of Cell Biology 43, 506-520.

Bligh, E. G. \& Dyer, W. J. (1959). A rapid method of total lipid extraction and purification. Canadian Journal of Biochemistry and Biophysiology 37, 911-917.

Brass, E. P. \& Ruff, L. J. (1992). Rat heptic coenzyme A is redistributed in response to mitochondrial acylcoenzyme A accumulation. Journal of Nutrition 122, $2094-2100$.

Chen, W. J. \& Anderson, J. W. (1984). Propionate may mediate the hypocholesterolemic effects of certain soluble plant fibres in cholesterol-fed rats. Proceedings of the Society for Experimental Biology and Medicine 175, 215-218.

Cummings, J. H., Pomare, E. W., Branch, W. J., Naylor, C. P. E. \& MacFarlane, G. T. (1987). Short chain fatty acids in human large intestine, portal, hepatic and venous blood. Gut 28, 1221-1227.

Dankert, J., Zijlstra, J. B. \& Wolthers, B. G. (1981). Volatile fatty acids in human peripheral and portal blood: quantitative determination by vacuum distillation and gas chromatography. Clinica Chimica Acta 110, 301-307.

Davis, R. A., McNeal, M. M. \& Moses, R. L. (1982). Intrahepatic assembly of very low density lipoprotein. Competition by cholesterol esters for the hydrophobic core. Journal of Biological Chemistry 257, 2634-2640.

De Water, R., Kamps, J. A. A. M., Van Dijk, M. C. M., Hessels, E. M. A. J., Kuiper, J., Kruijt, J. K. \& Van Berkel, T. J. C. (1992). Characterization of the low-density-lipoprotein-receptor-independent interaction of $\beta$ migrating very-low-density-lipoprotein with rat and human parenchymal liver cells in vitro. Biochemical Journal 282, 41-48.

Dietschy, J. (1986). Regulation of cholesterol metabolism in man and in other species. Klinische Wochenschrift 62 , 338-345.

Drevon, C. A., Weinstein, D. B. \& Steinberg, D. (1980). Regulation of cholesterol esterification and biosynthesis in monolayer cultures of normal adult rat hepatocytes. Journal of Biological Chemistry 225, 9128-9137.

Edge, S. B., Hoeg, J. M., Triche, T., Schneider, P. D. \& Brewer, H. B. (1986). Cultured human hepatocytes, Evidence for metabolism of low density lipoproteins by a pathway independent of the classical low density lipoprotein receptor. Journal of Biological Chemistry 261, 3800-3806. 
Forte, T. M., Nordhausen, R. W. \& Princen, H. M. G. (1989). Structural properties of lipoproteins isolated from human primary hepatocyte cultures. Arteriosclerosis 9, 693 a.

Gamble, W., Vaughan, M., Kruth, M. S. \& Avigan, J. (1978). Procedure for determination of free and total cholesterol in micro- or nanogram amounts suitable for studies with cultured cells. Journal of Lipid Research 19, 1068-1071.

Goldstein, J. L. \& Brown, M. S. (1980). Multivalent feedback regulation of HMG CoA reductase, a control mechanism coordinating isoprenoid synthesis and cell growth. Journal of Lipid Research 21, 505-517.

Gordon, M. J. \& Crabtree, G. (1992). The effects of propionate and butyrate on acetate metabolism in rat hepatocytes. International Journal of Biochemistry 24, 1029-1032.

Havekes, L. M., Verboom, H., De Wit, E., Yap, S. H. \& Princen, H. M. G. (1986). Regulation of low density lipoprotein receptor activity in primary cultures of human hepatocytes by serum lipoproteins. Hepatology $\mathbf{6}$, 1356-1360.

Hoeg, J. M., Edge, S. B., Demosky, S. J., Starzl, T. E., Triche, T., Gregg, R. E. \& Brewer, H. B. (1986). Metabolism of low-density lipoproteins by cultured hepatocytes from normal and homozygous familial hypercholesterolemic subjects. Biochimica et Biophysica Acta 876, 646-657.

Illman, R. J., Topping, D. L., McIntosh, G. H., Trimble, R. P., Storer, G. B., Taylor, M. N. \& Cheng, B. Q. (1988). Hypocholesterolemic effects of dietary propionate; studies in whole animals and perfused rat liver. Annals of Nutrition and Metabolism 32, 97-107.

Kalayoglu, M., Sollinger, H. W., Stratta, R. J., D'Allessandro, A. M., Hoffman, R. M., Pirsch, J. D. \& Belzer, F. O. (1988). Extended preservation of the liver for clinical transplantation. Lancet $\mathbf{i}, 617-619$.

Kamps, J. A. A. M., Kruijt, J. K., Kuiper, J. \& Van Berkel, T. J. C. (1991). Uptake and degradation of human low-density lipoprotein by human liver parenchymal and Kupffer cells in culture. Biochemical Journal 276, $135-140$.

Kirby, R. W., Anderson, J. W. \& Sieling, B. (1981). Oat-bran selectively lowers serum low-density lipoprotein concentrations of hypercholesterolemic men. American Journal of Clinical Nutrition 34, 824-829.

Kritchevsky, D. (1986). Dietary fiber and atherosclerosis. In Dietary Fiber, Basic and Clinical Aspects, pp. 265-274, [G. V. Vahouny and D. Kritchevsky, editors]. New York: Plenum Press.

Lowry, O. H., Rosebrough, N. J., Farr, A. L. \& Randall, R. J. (1959). Protein measurement with the Folin phenol reagent. Journal of Biological Chemistry 193, 265-275.

Nakanishi, M., Goldstein, J. L. \& Brown, M. S. (1988). Multivalent control of 3-hydroxy-3-methylglutaryl coenzyme A reductase. Mevalonate-derived product inhibits translation of $m$ RNA and accelerates degradation of enzyme. Journal of Biological Chemistry 263, 8929-8937.

Neese, R., Faix, D., Kletke, C., Wu, K., Wang, A. C., Shackleton, C. H. L. \& Hellerstein, M, K. (1993). Measurements of endogenous synthesis of serum cholesterol in rats and humans using Mass Isotopomer Distribution Analysis (MIDA). American Journal of Physiology 264, E136-E147.

Nishina, P. M. \& Freedland, R. A. (1990). Effects of propionate on lipid biosynthesis in isolated rat hepatocytes. Journal of Nutrition 120, 668-673.

Princen, H. M. G., Huijsmans, C. M. G., Kuipers, F., Vonk, R. J. \& Kempen, H. J. M. (1986). Ketoconazole blocks bile acid synthesis in hepatocyte monolayer cultures and in vivo in rat by inhibiting cholesterol $7 \alpha-$ hydroxylase. Journal of Clinical Investigation 78, 1064-1071.

Salhanick, A. I., Schwartz, S. I. \& Amatruda, J. M. (1991). Insulin inhibits apolipoprotein B secretion in isolated human hepatocytes. Metabolism 40, 275-279.

Sandker, G. W., Weert, B., Olinga, P., Wolters, H., Slooff, M. J. H., Meijer, D. K. F. \& Groothuis, G. M. M. (1994). Characterization of transport in isolated human hepatocytes. A study with the bile acid taurocholic acid, the uncharged ouabain and the organic cations vecuronium and rocuronium. Biochemical Pharmacology $\mathbf{4 0}$, 2193-2200.

Schouten, D., Kleinherenbrink-Stins, M. F., Brouwer, A., Knook, D. L., Kamps, J. A. A. M., Kuiper, J. \& Van Berkel, T. J. C. (1990). Characterization in vitro of interaction of human apolipoprotein E-free high density lipoprotein with human hepatocytes. Arteriosclerosis 10, 1127-1135.

Smit, M. J., Beekhuis, H., Duursma, A. M., Bouma, J. M. W. \& Gruber, M. (1988). Catabolism of circulating enzymes. Plasma clearance, endocytosis, and breakdown of lactate dehydrogenase-1 in rabbits. Clinical Chemistry 34, 2475-2480.

Todesco, T., Rao, A. V., Bosello, O. \& Jenkins, D. J. A. (1991). Propionate lowers blood glucose and alters lipid metabolism in healthy subjects. American Journal of Clinical Nutrition 54, 860-865.

Turley, S. D., Andersen, J. M. \& Dietschy, J. M. (1981). Rates of sterol synthesis and uptake in the major organs of the rat in vivo. Journal of Lipid Research 22, 551-569.

Turley, S. D. \& Dietschy, J. M. (1982). Cholesterol metabolism and excretion. In The Liver: Biology and Pathology, pp. 467-492 [I. Arias, H. Popper, D. Schachter and D. A. Shafritz, editors]. New York: Raven Press.

Wright, R. S., Anderson, J. W. \& Bridges, S. R. (1990). Propionate inhibits hepatocyte lipid synthesis. Proceedings of the Society for Experimental Biology and Medicine 195, 26-29. 